\title{
OPTIMISME KESEMBUHAN PADA PENDERITA MIOMA UTERI
}

\author{
A.M. Setyana Mega Cahyasari, Hastaning Sakti \\ Fakultas Psikologi Universitas Diponegoro \\ Jl. Prof. Sudharto SH, Tembalang, Semarang 50275 \\ sakti.hasta@gmail.com
}

\begin{abstract}
Uterine myoma (or uterine fibroid) is the most common tumour in female reproductive structure. It can bring physical impact, such as pain, abdominal discomfort, and abnormal bleeding. To cope with uterine myoma, optimism is needed to improve the psychological well-being of the affected women. Optimism was defined as a positive attitude in which person can achieve the expected normal health condition after suffering from uterine myoma. This study aims to describe the optimism of women diagnosed with a uterine myoma. This qualitative study used a phenomenological method. Two women diagnosed with uterine myoma participated in this study. Interview and observation were used to collect data. The findings showed that women affected uterine myoma had optimism and pessimism fluctuated. Optimism happened after they experienced particular events that changed their perscpective. Optimism empowered subjects to cope with uterine myoma. Factors that influence their optimism were social support received from family and others, sharing similar experience from other affected women, and religiosity. Optimism was also shown through their coping strategies in dealing with uterine myoma: seeking information, following treatment, applying nutrition diet, and maintaining health status.
\end{abstract}

Keywords: optimism, uterine myoma, uterine fibroid, phenomenology

\begin{abstract}
Abstrak
Mioma uteri merupakan tumor terbanyak pada organ reproduksi wanita, dan dapat menimbulkan dampak fisik berupa rasa nyeri, efek tekanan, serta pendarahan abnormal. Dalam menghadapi penyakit mioma uteri, diperlukan optimisme kesembuhan untuk meningkatkan kesehatan psikologis penderitanya. Optimisme kesembuhan diartikan sebagai sikap positif bahwa individu dapat mencapai harapan untuk kembali pada kondisi kenormalan kesehatan setelah menderita mioma uteri. Tujuan penelitian ini adalah untuk memahami optimisme kesembuhan pada penderita mioma uteri. Penelitian ini menggunakan metode kualitatif dengan pendekatan fenomenologis. Subjek penelitian adalah dua orang penderita mioma uteri. Metode pengumpulan data yang digunakan adalah wawancara dan observasi. Hasil penelitian menunjukkan bahwa penderita mioma uteri mengalami fluktuasi psikologis antara optimisme dan pesimisme. Optimisme kesembuhan muncul setelah subjek mengalami peristiwa tertentu yang menyebabkan perubahan pola pikir. Optimisme kesembuhan menjadikan subjek memiliki kekuatan dan keyakinan untuk mengatasi mioma uteri. Faktor-faktor yang mempengaruhi optimisme kesembuhan subjek ialah dukungan keluarga dan lingkungan, pengalaman orang lain, serta religiusitas. Optimisme kesembuhan yang dimiliki subjek dapat dilihat dari coping strategy yang dilakukan untuk mengatasi penyakit mioma uteri, yaitu berupa mencari informasi, melakukan pengobatan, menjalankan pola diet makanan, serta menjaga stamina tubuh.
\end{abstract}

Kata kunci: optimisme kesembuhan, mioma uteri, fenomenologi

\section{PENDAHULUAN}

Mioma uteri merupakan salah satu penyakit yang tumbuh di bagian organ reproduksi pada wanita. Mioma uteri ialah neoplasma jinak yang berasal dari otot uterus dan jaringan ikat sehingga dalam kepustakaan disebut juga leiomioma, fibriomioma, atau fibroid (Mansjoer, dkk., 2009). Neoplasma ialah pertumbuhan jaringan baru yang tidak normal pada tubuh, dan dikenal juga dengan istilah tumor (Dirckx, 2005). 
Mioma uteri merupakan tumor yang terbanyak pada organ reproduksi wanita (Tulandi, 2003). Di Indonesia, mioma uteri diderita oleh 2,39 - 11,7 \% wanita penderita penyakit organ reproduksi yang dirawat (Wiknjosastro, Saifuddin, \& Rachimhadhi, 2009). Mioma uteri jarang ditemukan pada wanita yang berusia 20 tahun, dan paling banyak ditemukan pada wanita usia 35-45 tahun. Penyebab utama penyakit ini belum diketahui secara pasti (Mansjoer dkk, 2001). Meskipun demikian, kemungkinan untuk memiliki mioma uteri dapat meningkat apabila ditemukan riwayat keluarga yang menderita mioma uteri, wanita dengan tingkat kesuburan yang rendah dan pada wanita yang belum pernah melahirkan (Wiknjosastro, Saifuddin, \& Rachimhadhi, 2009).

Mioma uteri menimbulkan gejala-gejala yang hanya dirasakan oleh 35-50\% dari penderita mioma uteri. Gejala yang ditimbulkan berupa pendarahan abnormal, rasa nyeri, dan rasa adanya tekanan di daerah sekitar panggul yang dapat menciptakan rasa sakit hingga menjalar ke punggung. Pendarahan abnormal rahim merupakan gejala yang paling sering dialami oleh $30 \%$ penderita mioma uteri (DeCherney \& Nathan, 2003).

Perubahan fisik yang terjadi akibat gejala mioma uteri membuat penyakit ini ditakuti oleh kaum wanita. Perubahan fungsi seksual merupakan perubahan yang berarti bagi seorang wanita dikaitkan dengan fungsi dan perannya dalam keluarga. Sebagai istri, perubahan fungsi seksual akan mempengaruhi kehidupan seksual individu dengan pasangan. Pasangan penderita dapat merasa takut melukai pasangan mereka ketika melakukan hubungan seksual (Burt \& Hendrick, 2005). Mioma uteri dapat mempengaruhi kehamilan seperti mening-katkan risiko keguguran (Wiknjosastro, Saifuddin, \& Rachimhadhi, 2009).
Pengobatan penyakit mioma uteri tergantung gejala yang dialami pasien, usia, status kehamilan, rencana reproduksi, kesehatan umum, serta ukuran dan lokasi dari mioma (DeCherney \& Nathan, 2003). Pembedahan merupakan pengobatan utama mioma uteri. Miomektomi merupakan pengambilan sarang mioma tanpa pengangkatan uterus/rahim (Wiknjosastro, Saifuddin, \& Rachimhadhi, 2009). Miomektomi merupakan pilihan untuk pasien yang ingin mempertahankan fertilitasnya (DeCherney \& Nathan, 2003).

Pengobatan mioma uteri menimbulkan efek pada penderita, yang dapat berdampak pada timbulnya permasalahan seksual, ketakutan akan kekambuhan penyakit, dan mengurangi rasa feminin karena kehilangan organ reproduksi. Perubahan fungsi seksual pada pasien wanita yang menjalani operasi organ reproduksi, merupakan hal yang memprihatinkan. Beberapa wanita merasa takut kehilangan feminitasnya setelah kehilangan organ reproduksinya (DeCherney \& Nathan, 2003). Hal ini berkaitan dengan kemampuan untuk memiliki keturunan yang dianggap sebagai bentuk kesempurnaan wanita (Stotland \& Stewart, 2001).

Pengobatan penyakit mioma uteri dapat menyebabkan dampak psikologis berupa tingginya level kecemasan sebelum dan sesudah operasi. Pengobatan dengan operasi juga dapat meningkatkan kegelisahan, depresi, marah, dan bosan. Beberapa penelitian menunjukkan penderita yang hendak melakukan operasi merasa khawatir dengan hasil akhir operasi (Ayers dkk, 2007).

Hasil wawancara awal terhadap dua orang penderita mioma uteri di Semarang menunjukkan bahwa kedua subjek mengalami gejala berupa pendarahan abnormal, rasa nyeri, dan adanya tekanan pada perut bagian bawah. Gejala-gejala 
tersebut berpengaruh pada kehidupan kedua subjek, yaitu subjek merasa kesakitan dan tidak dapat melakukan aktivitasnya sehari-hari. Subjek pertama (berinisial AA) juga memiliki ketakutan untuk melakukan operasi walaupun telah diharuskan menjalani operasi oleh dokter. Hal ini dikarenakan subjek AA merasa khawatir penyakitnya akan kambuh lagi setelah operasi. Berbeda dengan subjek AA, subjek kedua (berinisial JS) tidak menjalani operasi dikarenakan faktor ekonomi.

Subjek AA menyatakan bahwa terkadang subjek yakin bahwa penyakitnya dapat disembuhkan, namun terkadang subjek tidak yakin dapat sembuh dari penyakitnya. Di sisi lain, subjek JS memiliki keyakinan untuk sembuh. Keyakinan tersebut didukung dengan adanya motivasi pada diri subjek untuk merawat anak- anaknya, sehingga subjek berupaya melakukan berbagai pengobatan untuk mengatasi penyakit yang diderita.

Perubahan fisik yang dialami oleh penderita mioma uteri akibat dari gejala-gejala penyakit mioma uteri, serta dampak dari pengobatan yang harus dijalani oleh penderita mioma uteri dapat mempengaruhi kesehatan psikologis individu. Kesehatan psikologis merupakan hal yang mempengaruhi dan dipengaruhi oleh kesehatan fisik (Nevid, Rathus, \& Greene, 2005). Hal tersebut menjadikan optimisme kesembuhan diperlukan dalam meningkatkan kesehatan psikologis penderita mioma uteri.

Seligman (dalam Ghufron \& Rini, 2010) mengatakan bahwa optimisme adalah suatu pandangan secara menyeluruh, melihat hal baik, berpikir positif, dan mudah memberikan makna bagi diri. Optimisme ialah salah satu emosi positif yang berhubungan dengan masa depan (Seligman dalam Carr, 2004). Optimisme merupakan kemampuan yang dimiliki individu untuk meng- interpretasi secara positif kejadian dan pengalaman dalam kehidupannya. Optimisme membuat individu untuk tetap percaya bahwa individu dapat mencapai tujuan yang diinginkan, sedangkan pesimisme ragu akan kemampuannya (Baumgardner \& Crothers, 2010). Individu yang selalu berpengharapan baik dalam menghadapi segala hal disebut dengan optimis (Sugiono, 2008).

Carver dan Scheier (dalam Snyder \& Lopez, 2002) mendefinisikan optimisme sebagai sikap individu yang selalu memiliki harapan-harapan positif walaupun sedang dalam kondisi yang tidak menyenangkan. Optimisme membuat individu mengetahui apa yang diinginkan dan cepat mengubah diri agar mudah menyelesaikan masalah yang tengah dihadapi (Ghufron \& Rini, 2010). Individu yang memiliki optimisme merupakan individu yang mengharapkan hal-hal baik terjadi pada mereka, sedangkan individu yang pesimis adalah individu yang mengharapkan hal buruk terjadi atas mereka (Snyder \& Lopez, 2002).

Pesimis memiliki lebih banyak pandangan negatif dan memfokuskan pada apa yang hilang, sementara optimis memiliki pandangan positif, dan melihat apa yang tersedia. Psikologi melihat optimisme atau pesimisme sebagai perbedaan individual yang mendeskripsikan harapan positif atau negatif mengenai masa depan. Setiap individu memiliki tingkat optimisme atau pesimisme yang berbeda; dan perbedaan ini mempengaruhi aktivitas dan pilihan hidup (Baumgardner \& Crothers, 2010).

Seligman (2006) mengemukakan bahwa optimisme dan pesimisme mempengaruhi kesehatan. Optimisme dapat membantu meningkatkan kesehatan secara psikologis, sehingga diharapkan akan mempengaruhi perilaku individu ke arah yang positif. Carver dan Scheier (dalam Wade \& Tavris, 2007) menyatakan bahwa optimisme 
menimbulkan dampak yang lebih baik bagi kesehatan dan kesejahteraan individu dibandingkan dengan pesimisme.

Pada penderita mioma uteri, optimisme kesembuhan dapat membantu individu untuk meningkatkan kesehatan psikologis sehingga lebih bersemangat dalam menjalani hidup. World Health Organization (dalam Ogden, 2007) mendefinisikan kesehatan sebagai keadaan sehat utuh secara fisik, mental dan sosial. Kesembuhan merupakan perihal menjadi sehat kembali (Sugiono, 2008).

Optimisme membuat individu memiliki kesehatan yang lebih baik, jarang mengalami depresi, serta memiliki produktivitas kerja yang tinggi, apabila dibandingkan dengan individu yang cenderung pesimisme (Seligman, 2006). Optimisme menjadikan individu memiliki energi tinggi, serta bekerja keras untuk melakukan hal yang penting demi mencapai kesembuhan yang individu inginkan.

Optimisme kesembuhan pada penderita mioma uteri merupakan sikap positif bahwa individu dapat mencapai harapan untuk kembali pada kondisi kesehatan normal setelah menderita mioma uteri. Ketika individu memiliki optimisme untuk sembuh, maka individu akan memiliki kesehatan psikologis, sehingga tetap berusaha untuk melakukan hal-hal untuk mencapai kesembuhan, tidak putus asa, serta memiliki kepastian untuk memandang masa depan.

Penelitian ini bertujuan untuk memahami optimisme kesembuhan pada penderita mioma uteri. Pertanyaan yang diajukan dalam penelitian ini adalah bagaimana optimisme kesembuhan pada penderita mioma uteri?

\section{METODE}

Pendekatan kualitatif fenomenologis digunakan dalam penelitian ini. Perbedaan dan keunikan kondisi yang dialami oleh tiap individu menjadikan penelitian mengenai optimisme kesembuhan pada penderita mioma uteri dilakukan dengan meng-gunakan metode kualitatif fenomenologi.

Subjek terdiri dari dua orang yang dipilih dengan teknik purposive, yaitu subjek dipilih berdasarkan kriteria tertentu yang sesuai dengan masalah dan tujuan penelitian, yakni: (1) telah didiagnosa menderita penyakit mioma uteri oleh dokter; (2) belum melakukan pengobatan operatif namun sudah diharuskan menjalani operasi oleh dokter; (3) bersedia menjadi subjek penelitian dengan menandatangani informed consent.

Metode pengumpulan data yang digunakan adalah wawancara dan observasi. Analisis data dilakukan dengan mengikuti prosedur berikut: membuat dan mengatur data yang sudah dikumpulkan, membaca dengan teliti data yang sudah diatur, mendeskripsikan pengalaman di lapangan, horisonalisasi, unit-unit makna, deskripsi tekstural, deskripsi struktural, makna / esensi terdalam (Creswell, 2007).

\section{HASIL DAN PEMBAHASAN}

Subjek penelitian ini terdiri dari dua orang penderita mioma uteri, yaitu AA dan JS. Wawancara dengan subjek AA dilakukan sebanyak empat kali, sedangkan wawancara dengan JS dilakukan sebanyak tiga kali. Unit makna diperoleh dari hasil horisonalisasi, yakni dari ucapan subjek yang telah dimaknai secara psikologis. Unit makna yang diperoleh dari hasil penelitian ini terdiri dari latar belakang, persepsi, dampak, permasalahan yang 
dihadapi, resiliensi, perubahan pola pikir, optimisme kesembuhan, strategi coping, faktor yang mempengaruhi optimisme, pesimisme, serta pemulihan.

AA dan JS menderita mioma uteri pada rentang usia produktif. JS pertama kali menderita miom pada tahun 1997, saat berumur 30 tahun, sedangkan AA pertama kali pada tahun 2004 yaitu ketika berumur 39 tahun. Hal tersebut hampir serupa dengan pernyataan Wiknjosastro, Saifuddin, \& Rachimhadhi (2009) bahwa kelompok umur rata-rata munculnya simtom mioma uteri ialah umur 35 hingga 45 tahun. Mioma uteri ditemukan dalam 2025\% dari perempuan pada masa reproduksi (DeCherney\& Nathan, 2003).

Menjadi sakit merupakan kejadian yang penuh tekanan, ketika penyakit memberikan dampak terhadap kesehatan individu tersebut (Ogden, 2007). Dampak ini dapat berupa dampak fisik, perubahan aktivitas hidup, dan dampak psikologis. Penyakit mioma uteri dapat menimbulkan permasalahan-permasalahan tersebut. DeCherney dan Nathan (2003) mengungkapkan bahwa gejala fisik mioma uteri hanya dialami oleh $35-50 \%$ dari penderita mioma uteri.

Gejala fisik dari mioma uteri tergantung pada lokasi, ukuran, keadaan perawatan, dan apakah penderita hamil. Gejala yang dialami yaitu pendarahan abnormal pada uterus, rasa nyeri, dan efek tekanan. Subjek AA dan JS mengalami gejala-gejala tersebut. Pendarahan dialami JS ketika pertama kali terkena mioma uteri pada saat kehamilan anak pertamanya, dan pada saat kekambuhan mioma uteri JS setiap menstruasi mengalami pendarahan dalam jumlah yang banyak. Di sisi lain AA mengalami keluarnya cairah putih yang berlebihan pada vagina. DeCherney dan Nathan (2003) menyatakan bahwa perdarahan uterus abnormal adalah gejala klinis yang paling utama dari mioma uteri, dan dialami oleh $30 \%$ penderita.

Selain mengalami pendarahan, AA dan JS juga merasakan nyeri dan efek tekanan pada perut bagian bawah. Hal tersebut sesuai dalam DeCherney dan Nathan (2003) yang mengungkapkan bahwa tumor yang besar dapat menghasilkan sensasi berat di daerah panggul, sehingga menekan saraf dan menciptakan rasa sakit yang menjalar ke punggung. Nyeri pada saat hubungan seksual juga dapat terjadi, seperti yang dirasakan oleh AA.

Setelah didiagnosis menderita mioma uteri, AA dan JS berada dalam masa krisis. LeMaistre (1995) menyatakan bahwa pada tahap krisis individu akan mengalami shock dan ketakutan terhadap masa depannya. Walaupun pada saat pertama kali terdeteksi mioma uteri ketika masa kehamilan, JS merasa tidak begitu shock karena adanya dukungan suami, namun JS mencemaskan keadaan janin yang dikandungnya. Setelah mengalami kekambuhan munculnya miom kembali yaitu sepuluh tahun sesudah miom yang pertama, JS merasa shock dengan keadaan tersebut. Begitu pula yang dialami AA ketika didiagnosis menderita mioma uteri. Kedua subjek merasa shock karena diagnosa yang diberikan dokter merupakan hal yang tidak disangka sebelumnya (Greenberg, 2007). AA dan JS juga merasa tidak percaya dengan diagnosa tersebut. AA tidak menyangka akan terkena mioma uteri, sedangkan JS tidak menyangka akan mengalami kekambuhan pada saat itu.

Pada tahap krisis, individu akan mengalami ketakutan yang disebabkan oleh bayangan kematian (LeMaistre, 1995). Hal tersebut dialami pula oleh subjek AA dan JS bahwa mereka memiliki ketakutan dapat meninggal. Kognisi individu mengenai penyakitnya dapat mempengaruhi cara individu dalam memahami 
dan mengatasi penyakit (Ogden, 2007). AA memandang bahwa mioma uteri merupakan penyakit berbahaya sehingga AA memikirkan keadaan anak-anaknya apabila AA meninggal. JS juga cemas dengan kondisi anak-anaknya bila ia meninggal. Kecemasan merupakan salah satu respon terhadap penyakit yang serius (Greenberg, 2007). Selain berkaitan dengan kehilangan fungsi, kecemasan juga berkaitan dengan kehilangan kehidupan (Falvo, 2005). Kecemasan yang dialami JS dikarenakan rasa takut apabila penyakitnya semakin berkembang.

Saat menghadapi penyakit mioma uteri, AA awalnya menganggap peristiwa tersebut sebagai beban yang mempengaruhi kehidupannya. AA memandang bahwa masalah yang dialaminya sulit untuk diatasi. Individu yang membuat penjelasan universal untuk kegagalan, yaitu bahwa kegagalan sebagai musibah yang merusak segala aspek kehidupannya, individu tersebut akan menyerah kepada segalanya, serta cenderung hancur di bawah tekanan ketika kegagalan menimpa individu (Seligman, 2008).

Adanya mioma uteri mengharuskan AA untuk melakukan operasi pengangkatan miom, namun demikian AA merasa down dengan keharusan operasi tersebut. Pengobatan dengan operasi dapat menimbulkan kegelisahan yang tinggi serta depresi pada penderita penyakit (Ayers dkk, 2007). Rasa takut yang dialami AA disebabkan pengalaman traumatis ketika operasi kuret, yang membekas pada diri AA. Hal serupa juga dialami JS bahwa pengalaman operasi yang pernah dilakukannya mempengaruhi JS untuk tidak melakukan operasi. Seperti yang dinyatakan Ayers dkk (2007) bahwa penderita yang hendak melakukan operasi akan merasa khawatir berkaitan dengan hasil akhir operasi. Begitu pula yang dialami JS; ia merasa takut bila daya tahannya menurun dan timbul rasa tidak nyaman pada tubuh. Adanya pengalaman orang lain juga mempengaruhi timbulnya kekhawatiran bahwa akan mengalami kekambuhan walaupun telah operasi.

LeMaistre (1995) mengungkapkan bahwa tahap yang dialami penderita penyakit serius setelah tahap krisis ialah tahap isolasi, yaitu ketika kecemasan yang dialami individu mengakibatkan terganggunya hubungan sosial dengan orang lain. Selama tahap isolasi, individu mengalami perasaan negatif tentang diri mereka sendiri.Ketidakpastian mengenai masa depan juga berpengaruh pada citra diri.

Tahap isolasi tersebut dialami oleh AA. Adanya rasa sakit menjadikan nafsu makan AA menurun sehingga berat badan AA menjadi kurus. Hal tersebut mengakibatkan AA malu, sehingga AA cenderung menarik diri dan tidak ingin bertemu dengan teman-temannya. Penyakit yang diderita dapat menyebabkan individu terisolasi dari lingkungannya (Llewelyn \& Kennedy, 2003).

Dalam menghadapi penyakit serius, individu dapat mengalami kemarahan yang ditujukan kepada diri sendiri (LeMaistre, 1995). Kemarahan tersebut juga dapat ditujukan kepada orang lain yang berkaitan dengan kondisi yang dialami (Falvo, 2005). Penyakit mioma uteri yang diderita AA dan JS menyebabkan mereka marah karena mereka terkena penyakit tersebut. AA merasa tidak pernah menyakiti orang lain, sehingga AA merasa tidak adil dengan kondisi yang menimpanya. JS marah setelah membandingkan kondisinya dengan orang lain yang tidak mengalami nasib serupa.

Kemarahan yang dialami individu dapat menjadi hal yang positif atau negatif (LeMaistre, 1995). Untuk mengubah kemarahan menjadi hal yang positif diperlukan perubahan pola pikir menjadi pola pikir 
optimistis. Sebelum memasuki tahap rekonstruksi, AA dan JS melewati suatu resiliensi berupa kebangkitan yang membawa mereka pada optimisme untuk menghadapi penyakit mioma uteri.

Peristiwa yang dialami AA dan JS menyebabkan perubahan pola pikir pada diri mereka. Mereka berpikiran bahwa mereka harus melawan penyakit yang dideritanya. JS menerapkan pikiran bahwa JS mampu dan sanggup untuk menghadapi penyakitnya, sehingga dapat membesarkan kedua anaknya. JS juga mengubah pola pikirnya bahwa tiap-tiap orang memiliki kebahagiaannya masing- masing.

AA dan JS berusaha untuk menerapkan optimisme pada diri mereka. Menurut JS, optimisme ialah keyakinan serta kepercayaan diri bahwa ia mampu menepis halhal buruk yang terjadi dalam kehidupannya, sehingga ia dapat melangkah ke depan dengan pasti. JS optimis dirinya mampu melawan penyakit yang dideritanya. Hal tersebut serupa dengan pernyataan AA. Menurut AA, optimisme ialah keyakinan bahwa ia dapat sembuh dari penyakitnya, sehingga ia menerapkan pikiran tenang dan bersemangat dalam menghadapi sakitnya.

Menurut Wade dan Travis (2007), optimis berarti tidak menyangkal bahwa diri sendiri memiliki masalah atau menghindari berita buruk, sebaliknya optimis memandang masalah dan berita buruk sebagai kesulitan yang dapat diatasi. Hal tersebut menyebabkan optimisme dapat menjadikan kemarahan yang ada dalam diri individu menjadi kemarahan yang konstruktif dan sehat, sehingga dapat membuat individu memiliki kekuatan untuk menghasilkan sesuatu, meraih tujuannya, tidak membuang waktu dengan sia-sia dan membuka jalan menuju rekonstruksi. Adanya perubahan pola pikir menjadikan optimisme yang dimiliki AA dan JS memampukan mereka untuk melawan kemarahan dalam diri.
Scheier dkk (dalam Baumgardner, 2010) menyatakan bahwa orang yang optimis memiliki strategi penanganan masalah yang berbeda. Orang yang optimis cenderung mencari informasi, aktif mengatasi dan membuat perencanaan, mencari manfaat, dan menerima masalah. Saat menghadapi penyakitnya, AA dan JS berusaha untuk mengobati penyakitnya dengan melakukan pengobatan medis dan alternatif. Apabila mereka mendapat informasi tentang suatu pengobatan alternatif, mereka akan mendatangi tempat tersebut. Meskipun demikian, JS tetap memilah pengobatan yang akan diikuti. Bagi JS, apabila tidak yakin terhadap suatu pengobatan, maka tidak dapat sembuh, sehingga JS hanya memilih pengobatan yang diyakininya saja. Di sisi lain karena keterbatasan biaya, menyebabkan AA beralih ke pengobatan alternatif sepenuhnya.

Selain dengan melakukan pengobatan, AA dan JS juga menangani mioma uteri dengan menjaga pola makan, serta pantang beberapa jenis makanan yang berpengaruh terhadap perkembangan mioma uteri. Hal tersebut didukung dengan kesadaran yang dimiliki AA bahwa pada saat sebelum terkena mioma uteri, AA sering mengkonsumsi minuman yang mengandung pengawet serta jarang mengkonsumsi buah dan sayur. Oleh karena itu AA menduga pola makan yang tidak sehat sebagai penyebab dirinya menderita mioma uteri, walaupun penyebab dari mioma uteri belum diketahui secara pasti (Mansjoer dkk, 2001). JS juga beranggapan bahwa mengidap mioma uteri menjadikan dirinya harus lebih menjaga kesehatan dan pola makannya.

Keluarga, teman-teman, dan lingkungan sekitar dapat mempengaruhi optimisme individu (Seligman, 2008). Adanya dukungan dari keluarga dan lingkungan, semakin menumbuhkan semangat dan optimisme AA dan JS untuk sembuh. 
Keluarga dan lingkungan di sekitar AA memberikan motivasi kepada AA bahwa AA harus sembuh demi anak-anaknya dan tidak boleh berputus asa. Adanya dukungan tersebut membuat AA merasa terharu, serta mengubah pola pikir bahwa AA harus berusaha untuk memerangi penyakitnya, sehingga dapat memperoleh kesembuhan. Begitu pula dengan JS. Komunikasi yang terjalin antara JS dan anak-anaknya membuat JS semakin termotivasi dan optimistis untuk sembuh.

Bagi AA dan JS kesehatan merupakan hal yang penting. Dagun (2005) mendefinisikan sakit sebagai keadaan tidak nyaman pada tubuh karena menderita sesuatu. AA berpandangan bahwa adanya sakit menjadikan aktivitas kerjanya dalam melayani konsumen menjadi tidak maksimal. Demikian pula dengan JS, mioma uteri menjadikannya mudah lelah sehingga tidak dapat bekerja dengan maksimal. Kemampuan untuk melakukan aktivitas yang normal merupakan salah satu dimensi dari sehat (Ogden, 2007). Kesehatan menjadikan individu dapat menikmati hidup dan menjalani aktivitasnya dengan nyaman; oleh karena itu AA dan JS berusaha untuk menerapkan optimisme dalam mencapai kesembuhan yang mereka harapkan.

Optimisme memberikan pengaruh bagi kesehatan dalam beberapa cara. Optimisme menjadikan individu bertahan dari ketidakberdayaan. Individu menjadi tidak mudah menyerah. Individu optimistis akan lebih sedikit mengalami ketidakberdayaan berkepanjangan daripada individu pesimistis. Optimisme dapat mempengaruhi kesehatan individu selama masa kehidupan dengan mencegah ketidakberdayaan, sehingga membuat sistem kekebalan tubuh dapat berfungsi lebih baik (Seligman, 2008).

Optimisme dapat menghasilkan kesehatan yang lebih baik, berkaitan dengan tetap berpegang pada pola hidup sehat serta mencari bantuan medis ketika menderita penyakit. Individu optimistis mampu mengambil tanggung jawab terhadap diri sendiri untuk mendapatkan pengobatan segera setelah menderita penyakit. Individu yang memiliki optimisme lebih sehat daripada individu lain, berkaitan dengan dukungan sosial. Individu optimistis memiliki kemampuan untuk mempertahankan hubungan sosial dengan orang di sekitarnya. Individu yang pesimis menjadi pasif ketika masalah menghadang dan mengambil sedikit tindakan untuk mendapatkan dan mempertahankan hubungan sosial (Seligman, 2008).

Optimisme serta semangat untuk sembuh yang dimiliki AA dan JS menjadikan mereka dapat melangkah pada tahap rekonstruksi. Hal tersebut dikarenakan optimisme menyebabkan kemarahan dan rasa ketidakadilan yang ada dalam diri mereka berubah menjadi kekuatan dan keyakinan untuk mengatasi penyakit yang diderita, sehingga dapat melangkah menuju rekonstruksi. Menurut LeMaistre (1995), pada tahap rekonstruksi individu sudah kuat secara emosional, sehingga lebih mudah untuk bangkit tanpa ketakutan yang berlebihan. Pada masa ini, individu merasakan kembali dirinya masih dapat berfungsi, berharga, dan berguna.

Religiusitas memiliki pengaruh pada individu dalam pengembangan optimisme. Agama menimbulkan harapan dan memungkinkan individu menghadapi cobaan di dunia dengan lebih baik (Seligman, 2008). Agama menyediakan sistem kepercayaan menyeluruh yang mengizinkan individu untuk menemukan makna dalam kehidupannya serta harapan untuk masa depan (Seligman dalam Carr, 2004). Keikutsertaan individu dalam ritual rutin di pelayanan keagamaan dan menjadi bagian dari komunitas keagamaan memberikan dukungan sosial; keikutsertaan dalam 
kegiatan keagamaan seringkali terkait dengan gaya hidup yang lebih sehat secara fisik dan psikologis (Carr, 2004).

AA dan JS berkeyakinan bahwa penyakit merupakan pemberian dari Tuhan; oleh karena itu mereka memohon kepada Tuhan agar diberi kesembuhan. Mereka berpandangan bahwa sembuh atau tidak adalah tergantung Tuhan, sehingga mereka berkeyakinan dengan meminta pertolongan Tuhan maka Tuhan akan memberi kesembuhan kepada mereka. AA dan JS optimis, dengan pertolongan Tuhan mereka dapat sembuh.

Tahap rekonstruksi yang dialami individu tidak terlepas dari pemahaman terhadap pengalaman orang lain. Tumbuhnya optimisme dipengaruhi oleh pengalaman bersosialisasi dengan orang-orang di sekitar individu (Seligman, 2008). JS menceritakan temannya yang juga menderita sakit kronis, namun dia dapat bangkit, dan memiliki optimisme untuk berjuang melawan sakitnya, dan akhirnya dapat bertahan hingga sekarang. Hal tersebutlah yang mendukung JS untuk semakin optimis dapat memerangi penyakitnya dan memperoleh kesembuhan.

Pada kenyataannya, penderita mioma uteri terkadang mengalami pesimisme terhadap kesembuhan penyakitnya. Berdasarkan tahap depresi sementara menurut teori LeMaistre (1995), dikatakan bahwa ketika kehidupan menjadi lebih cerah, individu dapat menjadi lengah dan jatuh ketika depresi terjadi. Pada tahap ini, pesimisme muncul pada AA dan JS. Pesimisme adalah bagian dari pemikiran yang depresif. Konsep negatif mengenai masa depan, diri sendiri, dan dunia dibentuk dari pandangan terhadap penyebab-penyebab dari kejadian buruk yang bersifat permanen, menyebar ke segala aspek kehidupan, dan melihat penyebab suatu kejadian bukan dari diri sendiri (Seligman, 2008).
AA dan JS mengalami pesimisme ketika kondisi tubuh mereka sedang lelah dan rasa nyeri akibat mioma uteri kambuh, sehingga memacu munculnya pikiran-pikiran negatif. AA dan JS berpikiran mengapa penyakitnya tidak kunjung sembuh. Pemikiran tersebut membuat JS kembali memikirkan mengenai bagaimana nasib anak-anaknya apabila JS meninggal. Selain itu, ketika AA sedang seorang diri AA cenderung melamun sehingga muncul pikiran-pikiran negatif mengenai ketakutan AA untuk mengalami kekambuhan di masa depan.

Pesimisme yang dialami AA dan JS tidak berlangsung terus menerus. Seligman (2006) mengemukakan cara untuk mengubah pesimisme menjadi optimisme, yaitu dengan cara pengalihan pikiran, menjaga jarak, dan penyanggahan. Pengalihan meliputi melakukan sesuatu untuk menghentikan semua perhatian terhadap penjelasan pesimistis internal terhadap kemalangan yang menimpa individu. Penyanggahan lebih efektif dalam jangka panjang, karena berhasil menunjukkan bahwa keyakinan negatif yang dipikirkan sedikit kemungkinan akan terulang kembali ketika situasi yang sama terjadi lagi (Carr, 2004). Penyanggahan dilakukan dengan memberikan alasan untuk menentang pemikiran negatif. Menyanggah secara efektif pemikiran negatif dapat mengubah respon menjadi keaktifan dan semangat (Seligman, 2008).

JS berusaha mengalihkan pikirannya dengan melihat anak-anak. Bagi JS, anak merupakan tanggung jawab yang diberikan Tuhan kepadanya, sehingga JS berpikir dirinya harus kembali bangkit dan optimis untuk menyembuhkan penyakitnya. Optimisme AA dan JS juga timbul karena dukungan dan perhatian dari keluarga. Adanya dukungan dari keluarga yang berupa nasehat-nasehat agar AA mengubah pola pikirnya menjadi optimis, menyebabkan perlahan-lahan AA dapat 
menghilangkan pesimisme yang dimilikinya. AA terdorong untuk kembali menyembuhkan penyakitnya dengan cara mencari informasi mengenai tempat pengobatan ke orang di sekitarnya. Di samping itu AA mengubah pola pikirnya untuk berpikiran tenang dan optimis dalam menghadapi penyakitnya. Anak-anak JS turut memberikan perhatian kepada JS agar JS menjaga kesehatannya. Hal tersebut dijadikan JS sebagai motivasi untuk melawan penyakitnya, serta sumber optimisme yang dimiliki JS.

Seligman (2006) memaparkan optimisme terdiri dari tiga aspek, yaitu permanence, pervasiveness, dan personalization. Aspekaspek tersebut menjelaskan gaya individu dalam menanggapi peristiwa baik dan peristiwa buruk. Aspek permanence menjelaskan hal yang berkaitan dengan waktu, yaitu permanen/tetap dan temporer/ sementara. Seligman (2006) menjelaskan bahwa individu yang memiliki optimisme menganggap peristiwa baik memiliki penyebab yang permanen.

Individu yang menyerah mudah percaya bahwa penyebab kejadian buruk yang terjadi pada individu adalah hal yang bersifat tetap atau permanen (Seligman, 2008). Individu yang percaya bahwa kejadian baik mempunyai penyebab yang permanen, akan berusaha lebih keras setelah mengalami keberhasilan. Menurut AA saat ini kondisinya telah membaik, namun demikian AA merasa dirinya belum sembuh total. Keadaan tersebut justru menjadikan AA semakin berusaha untuk berobat agar mencapai kesembuhan total. Bagi AA peristiwa baik berupa pemulihan fisik yang dialaminya, dipengaruhi oleh adanya pikiran tenang yang AA terapkan dalam menghadapi penyakitnya.

Saat memandang mengenai peristiwa baik, JS menyatakan bahwa peristiwa baik tidak selalu ada dalam kehidupan karena terdapat juga peristiwa buruk. JS berpandangan adanya peristiwa buruk menjadikan individu mendekat kepada Tuhan, sedangkan apabila peristiwa baik selalu terjadi maka individu kurang berusaha untuk mendekat kepada Tuhan. Pandangan JS terhadap aspek permanen tersebut dipengaruhi adanya religiusitas yang dimilikinya.

Bagi JS, kesembuhan total atau sementara itu tergantung dari individu dalam menjaga kondisinya. Apabila JS mampu menjaga kondisinya, maka ia dapat sembuh total; namun bila ia tidak mampu menjaga kondisinya, maka kesembuhannya bersifat sementara. Saat memandang peristiwa mioma uteri, JS belum memiliki pemahaman bahwa penyakitnya berkepanjangan atau tidak, karena bagi JS penyakit berasal dari Tuhan sehingga tidak menutup kemungkinan akan diberi kesembuhan.

Aspek pervasiveness memaparkan tentang gaya penjelasan individu yang berkaitan dengan ruang lingkup (Seligman, 2006). Individu yang membuat penjelasan universal untuk kegagalan, menyerah pada segalanya ketika kegagalan menimpa individu, sedangkan individu yang membuat penjelasan yang spesifik dapat menjadi lemah di salah satu bagian dari hidup, namun tetap bertahan pada bagian yang lain. Orang yang optimis memiliki penjelasan spesifik terhadap suatu permasalahan sehingga hanya menciptakan ketidakberdayaan pada daerah yang tertimpa masalah saja (Seligman, 2008).

JS berpandangan bahwa penyakit mioma uteri hanya satu titik permasalahan di kehidupannya, sehingga JS tetap memiliki kebahagiaan pada titik lain di hidupnya. Dihadapkan dalam situasi yang buruk, individu yang memiliki optimisme akan menganggap situasi tersebut sebagai tantangan dan akan berusaha lebih keras (Seligman, 2006). JS berpandangan bahwa adanya penyakit jangan dijadikan sebagai masalah, namun jadikan sebagai tantangan 
yang harus dihadapi, sehingga JS harus berjuang untuk mengobati penyakitnya.

Aspek personalization berkaitan dengan sumber penyebab suatu peristiwa yang menimpa individu. Ketika hal buruk terjadi, individu dapat menyalahkan diri sendiri, atau menyalahkan orang lain atau keadaan. Individu yang menyalahkan diri sendiri ketika gagal, memiliki harga diri yang rendah sebagai konsekuensinya. Individu yang optimis cenderung menyalahkan peristiwa buruk yang menimpanya pada lingkungan eksternal. Individu yang menyalahkan pada kejadian eksternal tidak kehilangan rasa penghargaan terhadap dirinya sendiri saat kejadian buruk menimpanya (Seligman, 2008).

Dalam menghadapi penyakitnya, AA dan JS tidak menyalahkan dirinya sendiri sebagai penyebab mengalami mioma uteri. Walaupun JS telah mendapat nasehat dari pemuka agama untuk introspeksi diri apakah JS memiliki salah kepada orang lain sehingga JS menderita penyakit, namun JS tidak percaya begitu saja perkataan pemuka agama tersebut. Nasehat tersebut menjadikan JS memohon pengampunan dan kesembuhan dari Tuhan. AA dan JS mempercayai adanya pertolongan Tuhan dalam kehidupannya, sehingga mereka pasrah kepada Tuhan mengenai kondisinya. Sementara AA meyakini dirinya terkena mioma uteri karena pola makan yang tidak sehat.

AA telah menyadari tindakan-tindakan yang harus dilakukannya dalam mencapai kesembuhan. Begitu pula dengan JS yang menyadari bahwa JS harus tetap berjuang demi anak-anaknya. Keadaan AA dan JS serupa dengan tahap pembaharuan berdasar teori LeMaistre (1995), yaitu ketika individu telah menemukan kembali nilainilai hidupnya dan menjadikan mereka individu yang lebih baik.
Tahap pembaharuan ini berasal dari pengalaman yang mengajarkan untuk tidak menyia-nyiakan masa sekarang dan mencemaskan masa depan (LeMaistre, 1995). Di sisi lain, hal yang penting bagi individu ialah menyadari perubahan yang perlu dilakukan serta keterampilan yang harus dikuasai sehingga mampu mencapai harapan yang diinginkan. AA dan JS menyadari bahwa mereka harus memperbaiki dirinya dan berusaha untuk lebih menjaga makanan. Seligman (2008) menyatakan bahwa kondisi fisik merupakan salah satu faktor yang mempengaruhi optimisme pada individu. Adanya kontrol perilaku yang dilakukan AA dan JS, menjadikan kondisi fisik mereka membaik, dan mereka mengalami pemulihan psikologis. JS merasa senang dalam memandang masa lalunya karena ia mampu untuk mengatasi rasa sakit yang dialaminya, serta turut andil dalam upaya penyembuhannya. AA dan JS bersyukur kepada Tuhan karena perlahan- lahan Tuhan memberikan pemulihan kondisi dari masa lalu AA yang menderita penyakit. Pemulihan fisik dan psikologis yang dialami AA dan JS semakin meningkatkan semangat dan optimisme mereka untuk mencapai kesembuhan total seperti yang diharapkan.

\section{KESIMPULAN}

Optimisme kesembuhan dalam menghadapi penyakit mioma uteri dimiliki oleh kedua subjek. Optimisme kesembuhan muncul setelah subjek mengalami suatu peristiwa yang menyebabkan pola pikir subjek berubah. Optimisme kesembuhan menjadikan subjek mempunyai kekuatan dan keyakinan dalam mengatasi penyakit mioma uteri.

Berdasarkan temuan penelitian, penderita mioma uteri mengalami fluktuasi psikologis antara optimisme dan pesimisme. Subjek 
yang awalnya memiliki optimisme, dapat berubah menjadi pesimisme ketika nyeri sakitnya kambuh; tetapi dukungan dari keluarga menyebabkan subjek mengalami perubahan pola pikir menuju optimisme.

Optimisme kesembuhan kedua subjek dapat dilihat dari strategi coping yang digunakan, serta aspek-aspek optimisme kesembuhan yang dimiliki oleh kedua subjek. Aspek-aspek optimisme kesembuhan meliputi: cara pandang subjek terhadao peristiwa baik, cara subjek menjelaskan peristiwa buruk secara spesifik, dan cara subjek menjelaskan penyebab peristiwa yang dialaminya.

Peneliti selanjutnya diharapkan lebih mendalami mengenai faktor-faktor yang dapat mendukung dan memperlambat optimisme kesembuhan dan diharapkan dapat menemukan optimisme kesembuhan pada individu penderita sakit lainnya.

\section{DAFTAR PUSTAKA}

Ayers, S., Baum, A., McManus, C., Newman, S., Wallston, K., Weinman, J., \& West, R. (2007). Cambridge handbook of psychology, health and medicine. Cambridge: Cambrige University Press.

Baumgardner, S. R. \& Crothers, M. K. (2010). Positive psychology. Upper Saddle River: Pearson Education, Inc.

Burt, V. K. \& Hendrick, V. C. (2005). Clinical manual of women's mental health. Arlington: American Psychiatric Publishing, Inc.

Carr, A. (2004). Positive psychology: The science of happiness \& human strengths. Hove: Brunner-Routledge.
Creswell, J. W. (2007). Qualitative inquiry and research design: Choosing among five approaches. Thousand Oaks: Sage Publications, Inc.

Dagun, S. M. (2005). Kamus besar i Imu pengetahuan. Lembaga Pengkajian Kebudayaan Nusantara (LPKN).

DeCherney, A. H. \& Nathan, L. (2003). Current obstetric \& gynecologic diagnosis \& treatment. Boston: The McGraw-Hill Companies, Inc.

Dirckx, J. H. (2005). Kamus ringkas kedokteran Stedman untuk profesi kesehatan. Jakarta: Penerbit Buku Kedokteran EGC.

Falvo, D. (2005). Medical and psychosocial aspects of chronic illness and disability: Sudbury: Jones and Bartlett Publishers.

Greenberg, T. M. (2007). The psychological impact of acute and chronic illness. New York: Springer.

Ghufron, M. N. \& Rini, R. S. (2010). Teori-teori psikologi. Yogyakarta: AR-Ruzz Media.

LeMaistre, J. (1995). After the diagnosis: From crisis to personal renewal for patients with chronic illness. California: Ulysses Press.

Lewelyn, S. \& Kennedy, P. (2003). Handbook of clinical health psychology. West Sussex: John Wiley \& Sons, Ltd.

Mansjoer, A., Triyanti, K., Savitri, R., Wardhani, W.I., \& Setiowulan, W. (2001). Kapita selekta kedokteran. Jakarta: Media Aesculapius. 
Nevid, J. S., Rathus, S. A., \& Greene, B. (2005). Psikologi abnormal. Jakarta: Erlangga.

Ogden, J. (2007). Health psychology : A textbook. New York: McGraw Hill Open University Press.

Seligman, M. E. P. (2006). Learned optimism: How to change your mind \& your life. New York: Vintage Books.

Seligman, M. E. P. (2008). Menginstal optimisme: Bagaimana cara mengubah pemikiran dan kehidupan anda. Terjemahan: Budhy Yogapranata. Bandung: PT Karya Kita.

Snyder, C. R. \& Lopez, S. J. (2002). Handbook of positive psychology. New York: Oxford University.
Stotland, N. L. \& Stewart, D. E. (2001). Psychological aspects of women's health care: The interface between psychiatry and obstetrics and gynecology. Washington: American Psychiatric Press, Inc.

Sugiono, D. (2008). Kamus besar Bahasa Indonesia. Jakarta: Gramedia Pustaka Utama.

Tulandi, T. (2003). Uterine fibroids: Embolization and other treatments. Cambridge: Cambridge University Press.

Wade, C. \& Tavris, C. (2007). Psikologi. Jakarta: Penerbit Erlangga.

Wiknjosastro, H., Saifuddin, A. B., \& Rachimhadhi, T. (2009). Ilmu kandungan. Jakarta: PT Bina Pustaka Sarwono Prawirohardjo. 